\title{
Stabilization of iron regulatory protein 2, IRP2, by aluminum( Abstract_要旨)
}

AUTHOR(S):

Yamanaka, Koji

\section{CITATION:}

Yamanaka, Koji. Stabilization of iron regulatory protein 2, IRP2, by aluminum. 京都大学, 2000, 博士(医学)

\section{ISSUE DATE:}

2000-03-23

URL:

http://hdl.handle.net/2433/180826

RIGHT: 


\begin{tabular}{|c|c|c|}
\hline 氏 & 蚛 & 势 \\
\hline 学位(専攻分野) & 博 & 士 \\
\hline 学位記番号 & 医 & 博 \\
\hline
\end{tabular}

学位授与の日付平成 12 年 3 月 23 日

学位授与の要件 学位規則第 4 条第 1 項該当

研究科・専攻医学研究科脳統御医科学系専攻

学位論文題目 Stabilization of iron regulatory protein 2, IRP2, by aluminum

（アルミニウムは鉄イオン制御蛋白 IRP 2 の分解を抑制する）

論文調査委員主查) 教山卓教授成宮周教授柴崎浩

\section{論 文内容 の 要旨}

IRP (iron regulatory protein) はトランスフェリン受容体（TfR）やフェリチンの発現をRNA レベルで制御する鉄イオ ン代謝のマスター制御蛋白である。相同性の高い 2 種の IRP, IRP 1 と IRP 2 が存在し，いずれあ低鉄イオン濃度下でのみ RNA 結合活性を持つが, IRP 2 は鉄イオンによる酸化修飾がシグナルとなり, ユビキチンープロテアンーム経路で急速に分 解されることでその活性が制御されている。常に RNA 結合活性を持つ変異 IRP 1 を細胞株に導入すると細胞内鉄イオン濃 度が高くなり, 細胞死が起こることが報告されている。ほとんどの臟器, 細胞株に 2 種の IRP が発現しているが, IRP 2 の みしか発現していないマウス proB 細胞株 Ba/F 3 においても, TfRやフェリチンの発現は完全に制御されていることから, 鉄イオン濃度の制御にはIRP 2 のみの発現で十分であると考えられる。そこで鉄以外の全属イオンが IRP 2 の酸化や分解を 阻害し，安定化したIRP 2 にり遊離鉄イオン濃度が上昇し細胞障害を来す可能性を検討した。

まずマウス赤白血病細胞株 MEL をアルミニウム，マンガン，銅，亜鉛イオン存在下で培養し，IRP の RNA 結合活性を RNA ゲルシフトアッセイで, 蛋白量をウエスタンブロットで换討したところ, アルミニウム存在下でのみ IRP 2 の RNA 結 合活性が選択的に增強し，それは蛋白量の增加によるものであった。次に，様々な濃度の鉄とアルミニウム共存下で同様の 実験を行ったところ，アルミニウムは鉄イオンの効果に拮抗的に，かつ容量依存性にIRP 2 の分解を阻害した。また精製蛋 白を用いたインビトロの実験では, アルミニウムは鉄イオンによるIRP 2 の酸化修飾を抑制した。さらに MEL 細胞を用い たメタボリックラベルの実験では, アルミニウムによりTfRの增加, フェリチンの減少がみられ, IRP 2 の安定化を介して 細胞内鉄イオン代謝を障害する可能性が示唆された。これはマウス神経芽細胞腫株 Neuro $2 \mathrm{~A}$ や Ba/F 3 細胞にあ共通した 現象であった。

今回, 細胞内でアルミニウムは鉄イオンによるIRP 2 の分解を拮抗的に抑制し，またインビトロでアルミニウムは鉄イオ ンによるIRP 2 の酸化修飾を抑制することから, IRP 2 に鉄結合部位が存在することが示唆された。IRP 2 の鉄結合部位にそ れ自身酸化能のないアルミニウムが結合して鉄イオンによるIRP 2 の酸化修飾を抑制することが，アルミニウムによる細胞 内の IRP 2 の分解を阻害するメカニズムとして考えられる。今後鉄結合部位の同定や鉄イオンの結合様式の検索が, IRP 2 の分解の機序を明確にするうえで重要である。

また鉄イオン非依存性の因子によるIRP 2 の安定化は, 細胞内遊離鉄イオン濃度の上昇をあたらし, その結果ラジカル産 生を増加させて細胞障害を来すと考えられる。IRP 2 の発現は脳において高く, また神経変性疾患では病巣に鉄イオンの沈 着が認められることから, IRP 2 の安定化因子の探索は神経細胞障害の機序を明らかにするうえであ重要である。今回, 神経 細胞においてもアルミニウムが IRP 2 の RNA 結合活性增強因子であり, IRP 2 の安定化を介して細胞内の鉄イオン代謝を 障害する可能性が示された。神経疾患との関係については, アルミニウムの透析痴呆への関与は広く認められているが, そ の病巣に IRP 2 の蓄積が報告されているアルッハイマー病への関与は結論が出ていない。今後, IRP 2 の安定化因子のさら なる探索や，各種变性疾患での IRP 2 量を検討することが，鉄イオンと神経細胞障害との関係を明らかにするであろう。 


\section{論文蕃查の結果の要旨}

IRP (iron regulatory protein) はトランスフェリン受容体やフェリチンの発現を RNA レベルで制御する鉄イオン代謝の マスター制御蛋白であり, 高い相同性を有した 2 種の IRP, IRP 1 と IRP 2 が存在する。IRP 2 は鉄イオンによる酸化修飾が シグナルとなり，ユビキチンープロテアソーム経路で分解されるが，IRP 2 の酸化や分解に対する鉄以外の金属イオンの影 響は知られていない。さらに, IRP 1 の RAN 結合活性増強因子は鉄イオン代謝を障害しうることが報告されているが, IRP 2 の活性増強因子は明らかにされていなかった。

申請者はまず，培養細胞における IRP の RNA 結合活性を検出する系を確立し，アルミニウムが IRP 2 の RNA 結合活性 を增強する因子であることを明らかにした。次に，細胞内での IRP 2 の安定化の機序を解明するため，インビトロで IRP 2 蛋白の酸化修飾を検出する実験系を確立し，アルミニウムは鉄イオンによるIRP 2 の酸化修飾を抑制することを示した。さ らにアルミニウムの鉄イオン代謝への影響を検討するため, 細胞内のトランスフェリン受容体，フェリチンの産生量を検討 し，アルミニウムはIRP 2 を安定化させることにより細胞内鉄イオン代謝を障害しうることを示した。

以上の研究は鉄イオン代謝の調節機構と蛋白の分解機構の解明に貢献し，細胞生物学の進展に寄与するところが多い。 したがって，本論文は博士 (医学) の学位論文として価値あるあのと認める。

な抢，本学位授与申請者は，平成 12 年 1 月 14 日実施の論文内容とそれに関連した試問を受け，合格と認められたもので ある。 